\title{
Premature Babies and Associated Factors Among Births in Referral Hospitals of Amhara Region, Ethiopia: a Cross-sectional Study
}

Dagnew Getnet Adugna ( $\sim$ dagnewgetnet5@gmail.com )

University of Gondar College of Medicine and Health Sciences

Mohammed Oumar

University of Gondar College of Medicine and Health Sciences

Asmamaw Adugna

University of Gondar College of Medicine and Health Sciences

\section{Research}

Keywords: preterm birth, newborns, prevalence, associated factors, Gondar, Ethiopia

Posted Date: April 1st, 2021

DOl: https://doi.org/10.21203/rs.3.rs-378552/v1

License: (c) (i) This work is licensed under a Creative Commons Attribution 4.0 International License.

Read Full License 


\section{Abstract}

Background: Premature birth remains a serious public health problem in developing countries including Ethiopia. Ethiopia is one of the country with highest preterm birth rate in Africa. However, there is limited evidences on the prevalence and associated factors of premature birth. Therefore, this study was aimed to assess the prevalence and associated factors of premature birth among newborns delivered in Amhara region referral hospitals, Northern Ethiopia.

Methods: A hospital-based cross-sectional study was undertaken from February $23^{\text {rd }}$ to April $23^{\text {rd }}, 2020$, in the Amhara region. A total of 482 mother-newborn pairs were included in this study. The data were collected by interviewing the mothers and reviewing their charts using a structured and pretested questionnaire. The outcome variable was preterm birth. Data were entered using Epi-data version 4.6 and analyzed using STATA software (version 14). Bivariable and multivariable logistic regression models were done for the factors associated with premature birth.

Results: In this study, the prevalence of premature birth was $11.41 \%(95 \% \mathrm{Cl}: 8.9,14.6 \%)$. In multivariable logistig regression model; maternal age $<20$ years (Adjusted odds ratio (AOR) $=7.8: 95 \% \mathrm{Cl} 2.3-26$ ), preeclampsia $(A O R=5: 95 \% \mathrm{Cl} 2.3-11)$, premature rupture of membrane (AOR=3.9: 95\% Cl 1.6- 9.0), chronic medical illness (AOR=4.6:95\% $\mathrm{Cl} 2.1-10)$, and history of stillbirth ( $\mathrm{AOR}=2.7: 95 \% \mathrm{Cl} 1.1-7.3$ ) were significantly associated with preterm birth.

Conclusion: The finding of this study showed that the burden of premature birth is a public health concern among newborns delivered in Amhara region referral hospitals. Maternal age less than 20 years, preeclampsia, premature rupture of membrane, chronic medical illness, and history of stillbirth were factors associated with preterm birth. Therefore, efforts have to be made to reduce the burden of prematurity, and for early detection and management of preeclampsia. Premature rupture of membrane, and chronic medical illness. Obstetric care providers should give due attention to women with an age of less than 20 years and a history of stillbirth.

\section{Background}

Preterm birth (PTB) is defined as a live birth that occurred before 37 complete weeks of gestation or less than 259 days from the first day of the last normal menstrual period (LNMP) (1, 2). Worldwide, about 15 million (more than one in 10) babies are born preterm each year and about 12 million $(81 \cdot 1 \%$ ) of this prematurity occurs in Asia and sub-Saharan Africa (3). PTB is the largest direct cause of neonatal mortality and the second leading cause of under-five mortality following pneumonia (4). Each year, more than one million neonates die due to the consequence of prematurity (2). On average, $12 \%$ of births are born preterm in low-income countries compared to $9 \%$ in higher-income countries $9 \%(5,6)$.

The prevalence of PTB was highest in Africa and North America (11.9\% and 10.6\%, respectively), and lowest in Europe (6.2\%) (5). Moreover, studies done in Iran reported 5.1\% (7), Kenya 18.3\% (8), Nigeria 12 
$\%$ (9), Sweden 5.1\% (10), and Reliance Region (West of Algeria) 9.6\%(11). In Ethiopia, the magnitude of PTB varies from 4.4-25.9\% (12-17).

Studies conducted in different regions identified several risk factors for preterm birth such as having certain pregnancy-related conditions (preeclampsia, premature rupture of membrane (PROM), and antepartum hemorrhage (APH)), socio-demographic factors (low-income, large family number $(\geq 4)$, educational status and rural area residence) $(7-9,13,16-21)$. Besides, age $<20$ years, history of stillbirth, history of abortion, history of preterm, lack of antenatal care visit (ANC), short birth space, human immunodeficiency virus/ acquired immune deficiency syndrome (HIV/AIDS), anemia, visible congenital anomalies, induced labor, and presence of chronic illness were found to be significantly associated with PTB $(16,19,22-24)$. The contributing factors for PTB also include multiple pregnancies (25), maternal cardiovascular disease (26), and polyhydraminious (27).

PTB babies are suffering from long-term or short-term sequelae such as difficulty of breathing, feeding problems, cerebral palsy, the effect on brain development later in life, visual and hearing impairment, and poor prognosis. Besides, PTB is experiencing economic burdens at the individual, family, and social levels $(5,28)$. In developed nations, preterm baby survival rates are higher compared with developing nations. The difference may be due to better neonatal care set-up and low psychosocial inequality in higherincome countries than developing nations $(29,30)$.

PTB is an important public health problem in Ethiopia. However, there are limited researches on the prevalence and associated factors of PTB in some parts of Ethiopia. Besides, the prevalence and associated factors of PTB are different in various settings due to the discrepancy in the health care system and demographic features. Understanding the prevalence and associated factors of PTB is crucial to design effective public health programs and intervations to decrease the prevalence of PTB in the study area. Therefore, this study aimed to assess the prevalence and associated factors of PTB among newborns delivered in Amhara Region Referral Hospitals, Northern Ethiopia.

\section{Methods}

\section{Study Design, Period, and Study Setting}

An institution-based cross-sectional study was undertaken from February $23^{r}$ to April 23rd, 2020, in three randomly selected public referral hospitals: Gondar, Debre Tabor, and Bahir Dar Felege-Hiwot Referral Hospitals found in the Amhara Regional State, Ethiopia. The region has 67 public hospitals, 734 health centers, and 2941 health posts(31). There has seven referral hospitals, which serve more than 22 million people.

\section{Source and Study population}

The source population was all newborn-mother pairs delivered in the referral hospitals and the study population was all newborn-mother pairs delivered in the selected referral hospital during the study 
period.

\section{Inclusive and Exclusive criteria}

All newborn-mother pairs delivered at the selected public referral hospitals during the study period were included. Those mothers with unknown LNMP or absent early pregnancy ultrasound evidence $(\leq 20$ completed weeks of gestation) for gestational age (GA) calculation were excluded.

\section{Sample Size Determination and Sampling Procedure}

The sample size was calculated using a single population proportion formula by considering the confidence level (95\%), the margin of error $=3 \%$, and $11.6 \%$ of prevalence taken from the previous study done in Debremarkose, Ethiopia (32).

$$
\mathrm{n}=\frac{\left(\mathrm{Z}_{\alpha / 2}\right)^{2} * \mathrm{p}(1-\mathrm{p})}{\mathrm{d}^{2}} \quad \mathrm{n}=\frac{\left.(1.96)^{2 *}(0.116) *(1-0.116)\right)=}{(0.03)^{2}}
$$

By adding a $10 \%$ nonresponse, the final sample size was 482 . Governmental referral hospitals providing labor and delivery service in the Amhara Region were selected systematically. The sample size was proportionally allocated to each selected referral hospital prior to the start of actual data collection time, based on the previous hospital delivery report. The study participantswere selected from each hospital using a systematic sampling technique.

\section{Study Variables}

Dependent Variable: Preterm birth

Independent Variables

Socio-demographic, obstetric, medical, and newborn-related factors have been included. These are maternal age, marital status, educational status, residence, family size, occupational status, average monthly income, preeclampsia, APH, PROM, history of preterm birth, history of abortion, history of stillbirth, history of cesarean section, parity, interpregnancy interval, ANC follow-up status, the number of ANC visits, the onset of labor, chronic medical illness (maternal HIV, anemia, cardiac disease, and chronic kidney disease), and the sex of newborns.

\section{Operational Definition}

Preterm birth: A birth before 37 completed weeks of gestation but after 28 weeks (fetal viability) (23).

Family size: Number of family members such as her husband and numbers of children living together in one home.

\section{Data Collection Procedure and Tools}


The data were collected using a structured questionnaire through face-to-face interviews and reviewing the charts of the mothers. Socio-demographic and obstetric variables were collected through interviews after delivery when the mother becomes stable. Besides, clients, medical chart review has been undertaken to retrieve medical-related variables which might not be captured by interview. The questionnaire was prepared and utilized after reviewing various relevant literature. It was first developed in English, then translated into Amharic, and translated back into English for appropriateness and easiness in approaching study participants. The last normal menstrual period (LNMP) was confirmed from both her chart and through the interview. Newborns delivered before 37 completed weeks of gestation but after viability (28 weeks of gestation) were categorized as preterm. GA has been calculated based on her LNMP date or early pregnancy ultrasound report (up-to and including 20 completed weeks of gestation).

\section{Data Quality Control}

Before the actual data collection period, training was provided for data collectors and the questionnaires were pretested to $5 \%$ of the sample size at Debark General Hospital. Moreover, data collectors were supervised daily by the principal investigator, and the collected data were checked for completeness, consistency, and clarity before entry.

\section{Data Processing and Analysis}

The data were checked, coded, and entered into Epidata version 4.6, and exported to STATA version 14 software for analysis. Descriptive statistics like percentages, proportions, and mean are used. The results were presented in tables and text. A Chi-square test was done for categorical variables to check the assumptions. Binary logistic regression analysis was done since the outcome variable is binary. Both bivariable and multivariable binary logistic regression analysis was employed. Model fitness was assessed using the Hosmer-Lemeshow test. Variables with a p-value of less than 0.2 in the bivariable logistic regression were considered for the multivariable logistic regression analysis. In the multivariable logistic regression, the Adjusted Odds Ratio (AOR) with a 95\% confidence interval was used to determine the factors significantly associated with PTB.

\section{Results}

\section{Socio-demographic characteristics of the study participants}

A total of 482 study participants were enrolled in the study with a response rate of $100 \%$. The mean age $( \pm S D)$ of the mothers was 28.25 ( \pm 5.3 ) years and $63.7 \%$ of participant's ages were between the age group of $20-30$ years. Most 365 (75.7\%) participants were urban residents. In addition, $452(93.78 \%)$ of the mothers were married, $282(58.5 \%)$ had secondary education, $233(48.5 \%)$ were housewives. About $76.35 \%$ of the study participants had less than five family numbers (Table 1 ). 
Table 1

Socio-demographic characteristics of the study participants in Governmental Referral Hospital, Amhara Region, Northwest Ethiopia $2020(n=482)$.

\begin{tabular}{|c|c|c|c|}
\hline Variables & Category & Frequency & Percent (\%) \\
\hline \multirow[t]{3}{*}{ Age of the mother (years) } & $<20$ & 19 & 3.9 \\
\hline & $20-30$ & 304 & 63.7 \\
\hline & $\geq 31$ & 156 & 32.4 \\
\hline \multirow[t]{2}{*}{ Residence of the participants } & Urban & 365 & 75.7 \\
\hline & Rural & 117 & 24.3 \\
\hline \multirow[t]{3}{*}{ Ethnicity } & Amhara & 467 & 97 \\
\hline & Tigrie & 2 & 0.4 \\
\hline & Kimant & 13 & 2.6 \\
\hline \multirow[t]{2}{*}{ Religion } & Orthodox & 438 & 90.9 \\
\hline & Muslim & 44 & 9.1 \\
\hline \multirow[t]{3}{*}{ Marital status } & Married & 452 & 93.8 \\
\hline & Single & 17 & 3.5 \\
\hline & Divorced and separated & 13 & 2.7 \\
\hline \multirow[t]{4}{*}{ Educational status of the mothers } & Unable to read and write & 96 & 19.9 \\
\hline & read and write only & 39 & 8.1 \\
\hline & Primary Education & 65 & 13.5 \\
\hline & Secondary education and above & 282 & 58.5 \\
\hline \multirow[t]{6}{*}{ Mothers occupational status } & Housewife & 233 & 48.4 \\
\hline & Government employee & 121 & 25.2 \\
\hline & Nongovernment employee & 8 & 1.7 \\
\hline & Self-employed business & 89 & 18.6 \\
\hline & Daily laborer & 12 & 2.5 \\
\hline & Students and unemployed & 18 & 3.6 \\
\hline \multirow[t]{3}{*}{ Monthly income in Ethiopian Birr } & $\leq 1210$ & 12 & 2.5 \\
\hline & $1211-8970$ & 378 & 78.4 \\
\hline & $>8970$ & 92 & 19.1 \\
\hline
\end{tabular}




\begin{tabular}{|llll|}
\hline Variables & Category & Frequency & Percent (\%) \\
\hline Number of Family members & $\leq 4$ members & 368 & 76.3 \\
& $>4$ members & 114 & 23.7 \\
\hline
\end{tabular}

\section{Maternal obstetric, medical, and newborn characteristics}

In our study, the majority of 451 (93.4\%) mothers had ANC follow-up. Among them, $363(78.1 \%)$ had at least four visits during the current pregnancy. About 175 (36.3\%) of mothers were primiparous. Among the total mothers who gave birth during the study period, 48 (10\%) had PROM, 55 (11.4\%) had preeclampsia, and $40(8.3 \%)$ had APH. Concerning the mode of delivery, $264(54.8 \%)$ of mothers were delivered by spontaneous vaginal delivery. Moreover, $48(10 \%)$ had a history of stillbirth (Table 2$)$. 
Table 2

Maternal obstetric, medical and newborn characteristics of participants in Governmental Referral Hospital, Amhara Region, Northwest, Ethiopia 2020 ( $n=482)$

\begin{tabular}{|c|c|c|c|}
\hline Variables & Category & Frequency & Percent (\%) \\
\hline \multirow[t]{2}{*}{ ANC follow up } & Yes & 451 & 93.4 \\
\hline & No & 31 & 6.6 \\
\hline \multirow[t]{2}{*}{ Number of ANC visit } & $<4$ times & 99 & 21.9 \\
\hline & $\geq 4$ times & 352 & 78.1 \\
\hline \multirow[t]{3}{*}{ Pregnancy status } & Wanted and planned & 347 & 72 \\
\hline & Wanted but unplanned & 114 & 23.6 \\
\hline & Unwanted and unplanned & 21 & 4.4 \\
\hline \multirow{2}{*}{$\begin{array}{l}\text { Dietary counseling } \\
\text { during pregnancy }\end{array}$} & Yes & 425 & 88.2 \\
\hline & No & 57 & 11.8 \\
\hline \multirow[t]{2}{*}{ Parity } & Primiparous & 175 & 36.3 \\
\hline & Multiparous & 307 & 63.7 \\
\hline \multirow[t]{3}{*}{ GA at delivery } & Preterm & 55 & 11.4 \\
\hline & Term & 417 & 86.5 \\
\hline & Post-term & 10 & 2.1 \\
\hline \multirow[t]{2}{*}{ PROM } & Yes & 48 & 10 \\
\hline & No & 434 & 90 \\
\hline \multirow[t]{2}{*}{ Preeclampsia } & Yes & 55 & 11.4 \\
\hline & No & 427 & 88.6 \\
\hline \multirow[t]{2}{*}{$\mathrm{APH}$} & Yes & 40 & 8.3 \\
\hline & No & 442 & 91.7 \\
\hline \multirow[t]{2}{*}{ Chronic medical illness } & Yes & 65 & 13.5 \\
\hline & No & 417 & 86.5 \\
\hline \multirow[t]{4}{*}{ Types of medical illness } & HIV & 13 & 20 \\
\hline & Anemia & 26 & 40 \\
\hline & Urinary tract infection & 10 & 15.4 \\
\hline & Cardiac disease & 3 & 4.6 \\
\hline
\end{tabular}




\begin{tabular}{|c|c|c|c|}
\hline Variables & Category & Frequency & Percent (\%) \\
\hline & Others* & 13 & 20 \\
\hline \multirow[t]{2}{*}{ Previous history of PTB } & Yes & 36 & 7.5 \\
\hline & No & 446 & 92.5 \\
\hline \multirow[t]{2}{*}{ Previous history of stillbirth } & Yes & 48 & 10 \\
\hline & No & 434 & 90 \\
\hline \multirow[t]{2}{*}{ Previous history of abortion } & Yes & 44 & 9.1 \\
\hline & No & 438 & 90.9 \\
\hline \multirow[t]{3}{*}{ Modes of delivery } & Spontaneous vaginal delivery & 264 & 54.8 \\
\hline & Cesarean section & 203 & 42.1 \\
\hline & Instrumental delivery & 15 & 3.1 \\
\hline \multirow[t]{2}{*}{ Birth weight (g) of newborn } & $<2500$ & 64 & 13.3 \\
\hline & $\geq 2500$ & 418 & 86.7 \\
\hline \multirow[t]{2}{*}{ Sex newborn } & Male & 272 & 56.4 \\
\hline & Female & 210 & 43.6 \\
\hline
\end{tabular}

\section{Prevalence of PTB}

The prevalence of PTB was $11.4 \%$ (95\% Cl: 8.9, 14.6\%) and is presented in Table 2.

\section{Factors associated with PTB}

Binary logistic regression analysis was done using odds ratios (OR) and 95\% $\mathrm{Cl}$. Findings in bivariable analysis indicated that maternal age, residence, family size, ANC visits, preeclampsia, PROM, APH, chronic illness, previous history of stillbirth, previous history of abortion, and previous history of PTB was significantly associated with PTB at a p-value of 0.2. However, in the multivariable logistic regression analysis model; maternal age less than 20 years, preeclampsia, PROM, chronic medical illness during pregnancy (HIV, anemia, chronic kidney, and cardiac disease), and history of stillbirth were found to be significantly associated with PTB.

The likelihood of PTB among mothers in the age group less than 20 years of age was eight times higher compared to the mother's age group of $20-30$ years ( $A O R=7.8: 95 \% \mathrm{Cl} 2.3-26)$. Mothers with preeclampsia during pregnancy were about 5 times higher to give PTB than those who had no 
preeclampsia(AOR $=5: 95 \% \mathrm{Cl} 2.3-11)$. The odds of a mother with PROM were about 4 times more to give preterm birth than mothers with no PROM (AOR $=3.9: 95 \% \mathrm{Cl} 1.6-9.0)$.

Mothers who were exposed to chronic medical illness during pregnancy had 5-fold higher odds of PTB compared to those who were not exposed to any medical illness during this pregnancy $(A O R=4.6: 95 \% \mathrm{Cl}$ 2.1-10). Similarly, mothers with a history of stillbirth before this indexed pregnancy had 3 times higher odds of PTB compared to those mothers who did not have a history of stillbirth (AOR $=2.7: 95 \% \mathrm{Cl} 1.1-$ 7.3) (Table 3). 
Table 3

Factors associated with PTB among $(n=482)$ newborns delivered in Governmental Referral Hospital, Amhara Region, Northwest Ethiopia 2020.

\begin{tabular}{|c|c|c|c|c|c|}
\hline \multirow[t]{2}{*}{ Variables } & \multirow[t]{2}{*}{ Category } & \multicolumn{2}{|c|}{ Preterm birth } & \multirow{2}{*}{$\begin{array}{l}\text { COR } \\
(95 \% \mathrm{Cl})\end{array}$} & \multirow{2}{*}{$\begin{array}{l}\text { AOR } \\
(95 \% \mathrm{Cl})\end{array}$} \\
\hline & & YES & No & & \\
\hline \multirow[t]{3}{*}{ Age (years) } & $<20$ & 7 (12.7\%) & $12(2.8 \%)$ & $5.3(2-14)^{\star}$ & $\begin{array}{l}7.8(2.3- \\
26)^{*}\end{array}$ \\
\hline & $20-30$ & $30(54.6 \%)$ & $\begin{array}{l}277 \\
(64.9 \%)\end{array}$ & 1 & 1 \\
\hline & $\geq 31$ & $\begin{array}{l}18 \\
(32.7 \%)\end{array}$ & $\begin{array}{l}138 \\
(32.3 \%)\end{array}$ & $\begin{array}{l}1.2(0.6- \\
2.2)\end{array}$ & $\begin{array}{l}0.4(0.46- \\
1.0)\end{array}$ \\
\hline \multirow[t]{2}{*}{ Residence } & Urban & $31(56.4 \%)$ & $\begin{array}{l}334 \\
(78.2 \%)\end{array}$ & 1 & 1 \\
\hline & Rural & $\begin{array}{l}24 \\
(43.6 \%)\end{array}$ & $\begin{array}{l}93 \\
(21.8 \%)\end{array}$ & $\begin{array}{l}2.8(1.5- \\
4.9)^{\star}\end{array}$ & $\begin{array}{l}1.5(0.7- \\
3.2 .0)\end{array}$ \\
\hline \multirow[t]{2}{*}{ Family number } & $\leq 4$ & $35(63.6 \%)$ & $333(78 \%)$ & 1 & 1 \\
\hline & $>4$ & $\begin{array}{l}20(36.4 \\
\%)\end{array}$ & $94(22 \%)$ & $2(1.1-3.6)^{\star}$ & $\begin{array}{l}1.9(0.8- \\
4.9)\end{array}$ \\
\hline \multirow[t]{2}{*}{ ANC visit } & Yes & $44(80 \%)$ & $\begin{array}{l}406(95.1 \\
\%)\end{array}$ & 1 & 1 \\
\hline & No & $11(20 \%)$ & $\begin{array}{l}21(4.9 \\
\%)\end{array}$ & $\begin{array}{l}4.8(2.1- \\
10.6)^{\star}\end{array}$ & $2(0.7-6.0)$ \\
\hline \multirow[t]{2}{*}{ Preeclampsia } & Yes & $\begin{array}{l}19(34.6 \\
\%)\end{array}$ & $36(8.4 \%)$ & $\begin{array}{l}5.7(2.9- \\
11)^{\star \star}\end{array}$ & $\underset{* \star}{5(2.3-11)}$ \\
\hline & No & $\begin{array}{l}36(65.4 \\
\%)\end{array}$ & $\begin{array}{l}391 \\
(91.6 \%)\end{array}$ & 1 & 1 \\
\hline \multirow[t]{2}{*}{ PROM } & Yes & 18(32.7\%) & $30(7 \%)$ & $\begin{array}{l}6.4(3.2- \\
12)^{\star \star}\end{array}$ & $\begin{array}{l}3.9(1.6- \\
9.0)^{\star}\end{array}$ \\
\hline & No & $37(67.3 \%)$ & 397(93\%) & 1 & 1 \\
\hline \multirow[t]{2}{*}{$\mathrm{APH}$} & Yes & $9(16.4 \%)$ & $31(7.3 \%)$ & $\begin{array}{l}2.4(1.1- \\
5.6)^{\star}\end{array}$ & $\begin{array}{l}1.7(0.6- \\
4.6)\end{array}$ \\
\hline & No & $\begin{array}{l}46(83.6 \\
\%)\end{array}$ & $\begin{array}{l}396 \\
(92.7 \%)\end{array}$ & 1 & 1 \\
\hline \multirow[t]{2}{*}{$\begin{array}{l}\text { Chronic medical illness in } \\
\text { pregnancy }\end{array}$} & Yes & 18(32.7\%) & $47(11 \%)$ & $3.9(2-7.4)^{\star \star}$ & $\begin{array}{l}4.6(2.1- \\
10)^{\star \star}\end{array}$ \\
\hline & No & $37(67.3 \%)$ & $\begin{array}{l}380 \\
(89 \%)\end{array}$ & 1 & 1 \\
\hline
\end{tabular}




\begin{tabular}{|c|c|c|c|c|c|}
\hline \multirow[t]{2}{*}{ Variables } & \multirow[t]{2}{*}{ Category } & \multicolumn{2}{|c|}{ Preterm birth } & \multirow{2}{*}{$\begin{array}{l}\text { COR } \\
(95 \% \mathrm{Cl})\end{array}$} & \multirow{2}{*}{$\begin{array}{l}\text { AOR } \\
(95 \% \mathrm{Cl})\end{array}$} \\
\hline & & YES & No & & \\
\hline \multirow[t]{2}{*}{ Previous history of still birth } & Yes & $10(18.2 \%)$ & $38(8.9 \%)$ & $\begin{array}{l}2.2(1.0- \\
4.8)^{\star}\end{array}$ & $\begin{array}{l}2.7(1.1- \\
7.3)^{\star}\end{array}$ \\
\hline & No & $45(81.8 \%)$ & $\begin{array}{l}389 \\
(91.1 \%)\end{array}$ & 1 & 1 \\
\hline \multirow[t]{2}{*}{ Previous history of PTB } & Yes & $8(14.6 \%)$ & $28(6.6 \%)$ & $2.4(1-5.6)^{*}$ & $\begin{array}{l}1.8(0.6- \\
5.6)\end{array}$ \\
\hline & No & $\begin{array}{l}47(85.4 \\
\%)\end{array}$ & $\begin{array}{l}399 \\
(93.4 \%)\end{array}$ & 1 & 1 \\
\hline \multirow[t]{2}{*}{ Previous history of abortion } & yes & $\begin{array}{l}12 \\
(21.8 \%)\end{array}$ & $32(7.5 \%)$ & $\begin{array}{l}3.4(1.6- \\
7.1)^{*}\end{array}$ & $\begin{array}{l}1.7(0.7- \\
4.6)\end{array}$ \\
\hline & No & $\begin{array}{l}43(78.2 \\
\%)\end{array}$ & $\begin{array}{l}395 \\
(92.5 \%)\end{array}$ & 1 & 1 \\
\hline
\end{tabular}

\section{Discussion}

The study was aimed to assess the prevalence and associated factors of PTB among women who gave birth in the study area. In this study, the prevalence of PTB was $11.41 \%$. This study is in line with studies conducted in Africa (11.9\%) (5), North America (10.6\%) (5), Tanzania (14.2\%) (33), and Nigeria $12 \%$ (9). A similar finding was also obtained from studies at Axum, Tigray region (13.3\%) (23), and Debretabor town, Ethiopia (12.8\%) (15). This similarity between the present study and the previous studies in Axum and Debretabor may be due to various related levels of socioeconomic status and lifestyle of the respondents since all are low-income and middle-income countries.

The result of this study is lower than studies conducted in Kenya (18.3\%) (8) and Jimma, Ethiopia (25.9\%) (13). This discrepancy might be because multiple pregnancies were not included in this study since this may result in an over-distended uterus and can cause spontaneous preterm labor and delivery. The reason for this variation also might be due to the difference in the health-seeking behavior of the study participants and methodological differences. However, the finding in this study is higher than studies carried out in Iran (5.1\%) (7), Sweden (5.03\%) (10), and Gondar town, Ethiopia (4.4\%) (12). This variation could be due to the difference in the study time, inclusion and exclusion criteria, quality of health services, and socio-demographic characteristics.

The odds of giving PTB were higher among mothers who had preeclampsia, maternal age less than 20 years, PROM, chronic medical illness during pregnancy, and history of stillbirth.

Our findings revealed that the likelihood of PTB among mothers in the age group less than 20 years of age was eight times higher compared to the mother's age group of 20-30 years. This is consistent with a 
systematic review and meta-analysis conducted in East Africa (34). The study is also supported by studies done in Canada (35) and Ethiopia (22). This might be due to the age of mothers increases, their health-seeking behavior, and knowledge about pregnancy-related health problems will also be raised. Moreover, young women are more prone to many risk behaviors like alcohol consumption and less adherence to advice and counseling given by their health professionals compared to elder women(22).

Our study revealed that mothers who had preeclampsia had a 5 times increased risk of PTB than those who had no preeclampsia. This result is similar to a study carried out in Southern India (36), Kenya (8), Nigeria (37), Addis Ababa (18), Debremarkos (32), and a study conducted in public hospitals in Sidama zone, Southeast Ethiopia(19). This might be due to the complications of hypertension disease that can cause vascular damage to the placenta or decrease the uteroplacental blood flow. This induces oxytocin receptors and results in intrauterine growth restriction that causes preterm labor and delivery.

We found that mothers with PROM had four times 4 times more to give preterm birth than those with no PROM. This is consistent with the study done in Ghana (20), Nigeria (37), Kenya (8), Debretabor(15), and Sidama, Southeast Ethiopia (19). This could be because PROM raised fetal plasma interleukin-6 leading that the fetal response will activate preterm labor spontaneously (38). Furthermore, this might be explained by the influence of the membrane rupturing on uterine contraction. The research evidence claims that some endogenous uterotonic hormones are released when the membrane ruptures and these hormones, in turn, induce uterine contractions, triggering PTB.

Moreover, this study revealed that mothers who were exposed to chronic medical illness (HIV, anemia, chronic kidney disease, and cardiac disease) during pregnancy had 5-fold higher odds of PTB compared to those who were not exposed to any medical illness. This finding is supported by studies carried out in Jimma, Southwest Ethiopia(13), and Debremarkose, northwest Ethiopia (32), and a systematic review and meta-analysis of East Africa (34). This might be due to medical disorders during or before pregnancy affects the placenta and the membrane, in turn, reduces the placental flow of oxygen and nutrients to the developing fetus in utero, and, thus, increases the risk of preterm birth (39).

In our study, a mother who had a history of stillbirth had 3 times higher odds of PTB compared to those mothers who did not have a history of stillbirth. This study is in agreement with studies done in Sidama, Southeast Ethiopia(19), and a study conducted in Jimma, Southwest Ethiopia(13). This might be due to the recurrence of stillbirth in some women who initiate preterm labor in the preceding pregnancy.

\section{Limitations of the Study}

Being a cross-sectional study does not confirm a definitive cause-and-effect relationship. Since the study was hospital-based, it may not clearly show the real picture of PTB in the area.

\section{Conclusion}


The finding of this study indicated that the burden of premature birth is a public health concern among newborns delivered in Governmental Hospitals of Amhara Region. The study revealed that maternal age less than 20 years, preeclampsia, PROM, chronic medical illness during pregnancy, and history of stillbirth were found to be significantly associated with PTB. Therefore, efforts have to be made to reduce the magnitude of PTB, and for early detection and management of preeclampsia, PROM, and chronic medical illness. Obstetric care providers should give due attention to women with an age of less than 20 years and a history of stillbirth.

\section{Abbreviations}

ANC: Antenatal Care

AOR: Adjusted Odds Ratio

APH: Antepartum hemorrhage

Cl: Confidence Interval

COR: Crude Odds Ratio

GA: Gestational Age

HIV/AIDS: Acquired Immune Deficiency Syndrome/Human Immune Deficiency Virus

LNMP: Last Normal Menstrual Period

PROM: Premature Rupture of Membrane

PTB: Preterm Birth

STATA: Statistics/Data analysis

\section{Declarations}

\section{Authors' contributions}

D.G.A: conceived and designed the study, participated in the data collection process, analyze data, and wrote the manuscript. M.O and A.A: participated in data analysis, drafting of the manuscript and advising the whole research paper and also were involved in the interpretation of the data and contributed to manuscript preparation. All authors read and approved the final manuscript.

\section{Acknowledgments}


We would like to thank all study participants and data collectors for their great contributions to the success of this study. We would also like to acknowledge the University of Gondar for providing us ethical clearance and financial support for this study.

\section{Competing interests}

All authors declare that they have no competing interests for this work.

\section{Availability of data and materials}

The data sets used and analyzed during the current study available from the corresponding author on reasonable request.

\section{Consent for publication}

Not applicable.

\section{Ethical Approval and consent to participate}

Ethical clearance was obtained from the ethical review committee of the School of Medicine, College of Medicine and Health Sciences, University of Gondar. An official letter was submitted to the University of Gondar Comprehensive Specialized Hospital, Debre Tabor Hospital and Bahirdar Felege Hiwot Comprehensive Specialized Hospital. Written informed consent was taken from the study participants after a clear explanation of the purpose of the study. Confidentiality was maintained.

\section{Funding}

No funding was obtained for this study.

\section{References}

1. Lumley J. Defining the problem: the epidemiology of preterm birth. BJOG : an international journal of obstetrics and gynaecology. 2003;110 Suppl 20:3-7.

2. Lawn JE, Gravett MG, Nunes TM, Rubens CE, Stanton C, Group GR. Global report on preterm birth and stillbirth (1 of 7): definitions, description of the burden and opportunities to improve data. BMC pregnancy and childbirth. 2010;10(S1):S1.

3. Chawanpaiboon S, Vogel JP, Moller A-B, Lumbiganon P, Petzold M, Hogan D, et al. Global, regional, and national estimates of levels of preterm birth in 2014: a systematic review and modelling 
analysis. The Lancet Global Health. 2019;7(1):e37-e46.

4. Menon R. Preterm birth: a global burden on maternal and child health. Pathogens and global health. 2012;106(3):139.

5. Beck S, Wojdyla D, Say L, Betran AP, Merialdi M, Requejo JH, et al. The worldwide incidence of preterm birth: a systematic review of maternal mortality and morbidity. Bulletin of the World Health Organization. 2010;88:31-8.

6. Chang HH, Larson J, Blencowe H, Spong CY, Howson CP, Cairns-Smith S, et al. Preventing preterm births: analysis of trends and potential reductions with interventions in 39 countries with very high human development index. The Lancet. 2013;381(9862):223-34.

7. Alijahan R, Hazrati S, Mirzarahimi M, Pourfarzi F, Hadi PA. Prevalence and risk factors associated with preterm birth in Ardabil, Iran. Iranian Journal of reproductive medicine. 2014;12(1):47.

8. Wagura P, Wasunna A, Laving A, Wamalwa D. Prevalence and factors associated with preterm birth at Kenyatta national hospital. BMC pregnancy and childbirth. 2018;18(1):1-8.

9. Mokuolu OA, Suleiman B, Adesiyun O, Adeniyi A. Prevalence and determinants of pre-term deliveries in the University of Ilorin Teaching Hospital, Ilorin, Nigeria. Pediatric Reports. 2010;2(1).

10. Cnattingius S, Villamor E, Johansson S, Bonamy A-KE, Persson M, Wikström A-K, et al. Maternal obesity and risk of preterm delivery. Jama. 2013;309(22):2362-70.

11. AH M, MS K, Al B. Etiology of Preterm Birth in Relizane Region (West of Algeria). Nutrition \& Food Sciences. 2014.

12. Gebreslasie K. Preterm birth and associated factors among mothers who gave birth in Gondar Town Health Institutions. Advances in Nursing. 2016;2016.

13. Bekele I, Demeke T, Dugna K. Prevalence of preterm birth and its associated factors among mothers delivered in Jimma university specialized teaching and referral hospital, Jimma Zone, Oromia Regional State, South West Ethiopia. J Women's Health Care. 2017;6:356.

14. Belaynew W, Teumay A, Getachew G, Mohamed K. Effects of interpregnancy interval on preterm birth and associated factors among postpartum mothers who gave birth at Felege Hiwot referral hospital. World J Pharm Pharm Sci. 2015;4(4):12-25.

15. Mekonen DG, Yismaw AE, Nigussie TS, Ambaw WM. The proportion of preterm birth and associated factors among mothers who gave birth in Debretabor town health institutions, Northwest, Ethiopia. BMC research notes. 2019;12(1):2.

16. Kelkay B, Omer A, Teferi Y, Moges Y. Factors associated with singleton preterm birth in Shire Suhul general hospital, northern Ethiopia, 2018. Journal of pregnancy. 2019;2019.

17. Woldeyohannes D, Kene C, Gomora D, Seyoum K, Assefa T. Factors Associated with Preterm Birth among Mothers Who gave Birth in Dodola Town Hospitals, Southeast Ethiopia: Institutional Based Cross-Sectional Study. Clinics Mother Child Health. 2019;16(317):2.

18. Deressa AT, Cherie A, Belihu TM, Tasisa GG. Factors associated with spontaneous preterm birth in Addis Ababa public hospitals, Ethiopia: cross-sectional study. BMC pregnancy and childbirth. 
2018;18(1):332.

19. Sifer S, Kedir B, Demisse G. Determinants of preterm birth in neonatal intensive care units at public hospitals in Sidama zone, South East Ethiopia; a case-control study. J Pediatr Neonatal Care. 2019;9(6):180-6.

20. Aseidu EK, Bandoh DA, Ameme DK, Nortey P, Akweongo P, Sackey SO, et al. Obstetric determinants of preterm delivery in a regional hospital, Accra, Ghana 2016. BMC pregnancy and childbirth. 2019;19(1):248.

21. Taha TE, Dadabhai SS, Rahman MH, Sun J, Kumwenda J, Kumwenda NI. Trends in birth weight and gestational age for infants born to HIV-infected, antiretroviral treatment-naive women in Malawi. The Pediatric infectious disease journal. 2012;31(5):481.

22. Woday A, Muluneh MD. Determinants of preterm birth among mothers who gave birth at public hospitals in the Amhara region, Ethiopia: A case-control study. 2019;14(11):e0225060.

23. Aregawi G, Assefa N, Mesfin F, Tekulu F, Adhena T, Mulugeta M, et al. Preterm births and associated factors among mothers who gave birth in Axum and Adwa Town public hospitals, Northern Ethiopia, 2018. BMC research notes. 2019;12(1):640.

24. van den Broek NR, Jean-Baptiste R, Neilson JP. Factors associated with preterm, early preterm and late preterm birth in Malawi. PloS one. 2014;9(3):e90128.

25. Mulualem G, Wondim A, Woretaw A. The effect of pregnancy induced hypertension and multiple pregnancies on preterm birth in Ethiopia: a systematic review and meta-analysis. BMC research notes. 2019;12(1):1-7.

26. Wu P, Gulati M, Kwok CS, Wong CW, Narain A, O'Brien S, et al. Preterm delivery and future risk of maternal cardiovascular disease: a systematic review and meta-analysis. Journal of the American Heart Association. 2018;7(2):e007809.

27. Mahajan A, Magon S. Study of risk factors for preterm births in a teaching hospital: A prospective study. 2017.

28. Moster D, Lie RT, Markestad T. Long-term medical and social consequences of preterm birth. New England Journal of Medicine. 2008;359(3):262-73.

29. Dolatian M, Mirabzadeh A, Forouzan AS, Sajjadi H, Alavimajd H, Mahmoodi Z, et al. Relationship between structural and intermediary determinants of health and preterm delivery. Journal of reproduction \& infertility. 2014;15(2):78.

30. Snelgrove JW, Murphy KE. Preterm birth and social inequality: assessing the effects of material and psychosocial disadvantage in a UK birth cohort. Acta obstetricia et Gynecologica Scandinavica. 2015;94(7):766-75.

31. Mekuriyaw AM, Mihret MS. Determinants of Preterm Birth among Women Who Gave Birth in Amhara Region Referral Hospitals, Northern Ethiopia, 2018: Institutional Based Case Control Study. 2020;2020:1854073.

32. Bekele T, Amanon A, Gebreslasie KZ. Pre-term birth and associated factors among mothers who gave birth in Debremarkos town health institutions, 2013 institutional based cross-sectional study. 
Gynecol Obstet. 2015;5(5):292-7.

33. Temu TB, Masenga G, Obure J, Mosha D, Mahande MJ. Maternal and obstetric risk factors associated with preterm delivery at a referral hospital in northern-eastern Tanzania. Asian Pacific Journal of Reproduction. 2016;5(5):365-70.

34. Laelago T, Yohannes T, Tsige G. Determinants of preterm birth among mothers who gave birth in East Africa: systematic review and meta-analysis. Italian journal of pediatrics. 2020;46(1):10.

35. Fuchs F, Monet B, Ducruet T, Chaillet N, Audibert F. Effect of maternal age on the risk of preterm birth: A large cohort study. PloS one. 2018;13(1):e0191002.

36. Rao CR, de Ruiter LE, Bhat P, Kamath V, Kamath A, Bhat V. A case-control study on risk factors for preterm deliveries in a secondary care hospital, southern India. International Scholarly Research Notices. 2014;2014.

37. Mokuolu OA, Suleiman B, Adesiyun O, Adeniyi A. Prevalence and determinants of preterm deliveries in the University of Ilorin Teaching Hospital, llorin, Nigeria. Pediatric Reports. 2010;2(1).

38. Gravett MG, Adams KM, Sadowsky DW, Grosvenor AR, Witkin SS, Axthelm MK, et al. Immunomodulators plus antibiotics delay preterm delivery after experimental intraamniotic infection in a nonhuman primate model. American journal of obstetrics and gynecology. 2007;197(5):518. e1-. e8.

39. Behrman RE, Butler AS. Preterm birth: causes, consequences, and prevention. 2007. 